\title{
Gibbago trianthemae Simmons, a Biocontrol Agent of Horse Purslane Weed: Research and Prospect
}

\author{
Gaddeyya Gandipilli ${ }^{1}$, Kaiding Ratna Kumar Peethala ${ }^{1}$ and Bharathi Pilaka ${ }^{2}$ \\ 1. Department of Botany, Andhra University, Visakhapatnam 530003, India \\ 2. Government Degree College, Chodavaram 531036, Andhra Pradesh, India
}

\begin{abstract}
Trianthema portulacastrum L. (commonly known as horse purslane) is a noxious weed of several economically important field crops in tropical regions of the world. An intensive work on the screening of the biocontrol agents was accomplished through in vitro epidemic study to control weed populations. The foliar disease symptoms on infected weed plants caused by fungal pathogens represented as round to irregular maroon spots with dark borders and the epidemic was identified as leaf spot disease. The pathogen allied with the infection of horse purslane was isolated from infectious propagules by inoculation of leaf bites on a nutrient medium, potato dextrose agar (PDA). The causal agent of leaf spot was confirmed as Gibbago trianthemae Simmons by Koch's postulates. The mycoherbicide ability of G. trianthemae has been examined through visual (standard area diagram) and statistical methods (analysis of variance using the Microsoft Office Excel-Data Analysis Tool Pack 2007). The results revealed that the pathogen causes significantly $(P<0.05)$ severe infection on host weed and destructs the weed population by leaf spot diseases. The findings of the research suggested that the isolate $G$. trianthemae is highly virulent and host-specific, and recommended for further studies as a promising biocontrol agent against horse purslane weed.
\end{abstract}

Key words: T. portulacastrum L., G. trianthemae Simmons, mycoherbicide, PDA, percent disease index.

\section{Introduction}

Trianthema portulacastrum L., commonly known as horse purslane, black pigweed, carpet weed, gudbur and hogweed, belongs to the family Aizoaceae. It is indigenous to South Africa and presently occurs in tropical and subtropical areas throughout the world, and is considered as an aggressive weed in food crops and vegetables [1]. It has become a noxious weed and attained a status of number one troublesome weed in agricultural fields because of the loss of yield due to competition for nutrition, sunlight, water and habitat. Currently, horse purslane is controlled by common agricultural practices, like hand weeding and mechanical weeding, but these methods are insufficient to control population of the weed. Chemical herbicides, such as acifluorfen, alachloral, atrazine, bentazon, fluchloralin, fomesafen, paraquat

Corresponding author: Gaddeyya Gandipilli, Ph.D., research fields: biological control of weeds and plant pathology. and pyruvate, are also used to control horse purslane to achieve the immediate elimination of weed population [2]. Nevertheless, the excessive utilization of herbicides leads to the contamination of soil and ground water, which causes the adverse affects on other flora and fauna including human beings. Biological weed control is an approach to utilizing living organisms to control or reduce the population of an undesirable plant (weed). The classical or inoculative approach involves the importation and release of one or more natural enemies that attack the target weed.

The awareness on conservation of biodiversity and control of environmental pollution demands the exploitation of microorganisms as pest and weed control agents. Especially plant pathogenic fungi are now emerging as an effective and eco-friendly alternative to conventional methods of weed control [3]. Biological control of weeds has more advantages over mechanical and chemical methods, and can be 
specific to the target weed and does not lead to residue problems and accumulation of toxic pollutants in the soil or underground water $[4,5]$. The common control methods against horse purslane weed are very expensive, time-consuming and labour intensive. Although chemical herbicides are the most effective immediate solution to the control of weeds, but the increase and indiscriminate use of chemical compounds results in resistance of weed and also causes soil and environmental pollution. While, biological control of weeds has advantages over mechanical and chemical methods of weed control. As an alternate method to chemical herbicides, the uses of biological control agents were introduced successfully since last few decades. The procedure, biological control of weeds, became as a component in integrated weed management. Integrated weed management is a viable component of integrated pest management.

An exploration on fungal plant pathogens as weed biocontrol agents have been increased with discovery and extensive study of pathogenicity, adaptability, dispersal and survival efficiency of the pathogens. These studies accounted in part for the development of the mycoherbicides, and some of these pathogens were biologically successful at field conditions. On the basis of the fundamental research and scientific literature on the exploitation of microbial agents for weed control, systematic field observations were made at agricultural fields of Visakhapatnam district in Andhra Pradesh, India, and an epidemic study was undertaken on $T$. portulacastrum L. (horse purslane) to implement biological control of weed populations for sustainable agriculture.

\section{Materials and Methods}

\subsection{Sample Collection}

The diseased plants and propagules were collected randomly from highly infected leaves of horse purslane weed in agricultural fields at Visakhapatnam district, Andhra Pradesh, India. Plant materials were taken into sterilized polythene bags and brought to the laboratory for the extensive study on symptoms, isolation and pathogenicity of the organism(s) involved in leaf spot disease. The disease symptoms on leaves, stems and other plant parts were critically examined in Plant Pathology Laboratory, Department of Botany, Andhra University, Visakhapatnam.

\subsection{Isolation, Identification and Subculture of Fungal Pathogens}

The diseased leaves were washed thoroughly in running tap water to remove soil particles, and the infected portions of the leaves were cut into 1.0-1.5 $\mathrm{cm}$ fragments. The pieces were surface sterilized by $70 \%$ ethyl alcohol for 1-2 min and then rinsed in sterile distilled water for three to four times. Finally, the leaf bits were rinsed in $0.01 \%$ mercuric chloride for $1 \mathrm{~min}$ or $2 \mathrm{~min}$, followed by washing with sterile, autoclaved double-distilled water for two or three times. These fragments or leaf bits were transferred on to Czapek Dox agar (CZA, Himedia) and potato dextrose agar (PDA) plates supplemented with $1 \%$ streptomycin sulphate and penicillin (antibiotics) under sterile conditions in an inoculation chamber. After inoculation, plates were incubated at $26 \pm 2{ }^{\circ} \mathrm{C}$ for $21 \mathrm{~d}$ on a $12 \mathrm{~h} \mathrm{light/dark}$ photoperiod. The isolates were purified by separation of small aerial mycelial fragments with inoculation loop on to new culture plats at the initial growth of fungal colonies. The stock cultures of the isolates were prepared using mono culture (single conidial culture) and stored at room temperature as slant cultures on PDA media. The isolates were examined by the staining techniques, and diagnostic characteristics of the isolates were examined under light microscope. Identification and taxonomic features of the isolates were made with help of the relevant literature [6-10]. The isolates were properly sub-cultured on PDA and CZA for further research and maintained in PDA slants at $26 \pm 2{ }^{\circ} \mathrm{C}$ in Plant Pathology Laboratory, Department of Botany, Andhra University, Visakhapatnam. 


\subsection{Inoculum Production of Test Pathogen}

The young and well sporulating isolates of $G$. trianthemae were used for the assay of disease intensity at in vitro conditions. After 12-14 d of incubation, the spore suspensions were harvested from each culture by adding $20 \mathrm{~mL}$ of sterile distilled water and scraping of mycelium surface with a sterile glass rod or camel hair brush. The resulting slurry of spores and mycelial fragments was filtered with 3-4 folded cheesecloth, and filtrate was taken into 250 $\mathrm{mL}$ conical flasks. Spore suspensions were centrifuged at 3,500 rpm for $20 \mathrm{~s}$ for purification of filtrated spores, and the optimum spore concentrations were enumerated using a haemocytometer. An aqueous conidial suspension (5 $\times 10^{4}$ spores $/ \mathrm{mL}$ ) of the fungus was prepared and standardized with haemocytometer. An optimum concentration of Tween-20 (0.02\% v/v) was added as wetting agent to the conidial suspension before application of the spore treatment of test plants.

\subsection{Inoculation of Test Plants}

Inoculations were made on young plants growing under greenhouse conditions up to spore treatment. The plants with young leaves (at 6-8 leaf stage) were inoculated with an optimal conidial suspension $(5 \times$ $10^{4}$ spores $/ \mathrm{mL}$ spore inoculum $+0.02 \%$ Tween-20) of G. trianthemae by hand sprayer after sunset (between 6:00 pm and 7:00 pm) to avoid drying of the spores. After inoculation, leaves were enclosed with sterile polythene bags for $48 \mathrm{~h}$ to maintain $100 \%$ humidity for feasibility of the spore germination. Control plants were treated in the same manner, except that they were sprayed with sterile water $+0.02 \%$ Tween- 20 . The adjuvant Tween-20 was applied as a wetting agent. After inoculation experiment, leaves were collected from both test plants (spore treated) and control plants (water treated) at $10 \mathrm{~d}$ of intervals to examine the virulence of pathogen. For in vitro experiments, both the control plants and test plants were maintained in five replicates. Each replicate contains $10 \mathrm{bags} /$ pots (two plants per one pot). A total of 200 plants (100 control plants and 100 test plants) were maintained for each experiment. An average of 60 leaves was examined in each replicate for the assessment of disease severity of the test pathogen.

\subsection{Measurement of Disease Intensity}

The intensity of disease was measured in terms of disease incidence [11] and disease severity [12]. The disease severity was examined at $10 \mathrm{~d}$ of interval, and the leaf spot disease was evaluated using standard area diagram of infected leaves. The quantitative data on disease severity were calculated using the analysis of variance, as following Eqs. (1) and (2):

$$
\begin{aligned}
& \text { Disease incidence }(\%)=\frac{\text { No. of diseased plants }}{\text { No. of total plants inspected }} \\
& \times 100 \\
& \text { Disease severity (PDI) }= \\
& \frac{\text { sum of all ratings }}{\text { No. of leaves observed } \times \text { the hightest rating }} \times 100
\end{aligned}
$$

where, the sum of all numerical ratings $=$

$$
\begin{aligned}
& \left(0 \times N_{0}\right)+\left(1 \times N_{1}\right)+\left(2 \times N_{2}\right)+\left(3 \times N_{3}\right)+ \\
& \left(4 \times N_{4}\right)+\left(5 \times N_{5}\right)
\end{aligned}
$$

$N_{0}$ : the number of leaves with score 0 ;

$N_{1}$ : the number of leaves with score 1 ;

$N_{5}$ : the number of leaves with score 5 .

For the estimation of leaf area diseased, the whole leaf surface area was considered as 100, and thereby the infected area was determined by eye estimation for percent of disease index (PDI), i.e., disease severity. Disease intensity and severity were rated by visual observation, and the infected leaves were scored using a $0-5$ scale rating system [13] (Table 1). Using this rating system, a disease index (DI) was calculated per observations made at an interval of $10 \mathrm{~d}$ after treatment. For the assessment of disease severity, individual leaf ratings were taken into an account until the death of the weed. 
Table 1 0-5 disease rating scale used to assess the severity of symptoms on horse purslane.

\begin{tabular}{ll}
\hline $\begin{array}{l}\text { Disease rating } \\
\text { scale }\end{array}$ & Disease description \\
\hline 0 & No symptoms \\
1 & $1 \%-10 \%$ of the leaf area covered by spots \\
2 & $11 \%-25 \%$ of the leaf area covered by spots \\
3 & $26 \%-50 \%$ of the leaf area covered by spots \\
4 & $51 \%-75 \%$ of the leaf area covered by spots \\
5 & $\geq 75 \%$ of the leaf area covered by spots \\
\hline
\end{tabular}

\subsection{Statistical Analysis}

The data were analyzed by mean \pm standard error (SE) and analysis of variance using the Microsoft Office Excel-Data Analysis Tool Pack 2007.

\section{Results and Discussion}

\subsection{Identical Characteristics of $G$. trianthemae Simmons}

The identification features of the isolates, such as colony diameter, colour, texture, sporulation, the shape and sizes of conidiophores and conidia, were carefully studied. The causal agent of leaf spot disease of horse purslane was isolated from wild plants and simultaneously from test plants inoculated with spore suspension. The pathogenicity of the isolate was confirmed by Koch's postulates, and the host specificity of the pathogen was tested using repeated spore treatments and reisolation of causal agent. At maturity stage, the profuse radial growth and sporulation of a fungal pathogen were recorded, and the isolate was confirmed as G. trianthemae Simmons by microscopic study of mycelium, conidia and conidiophores. Inoculated leaf lesions yielded white colored colonies of $G$. trianthemae at initial stage on the surface of nutrient media. Subsurface mycelial growth was dense and dark on PDA, and inconspicuous on tap water agar (TWA). Sporulation was excellent at agar surfaces of CZA, and the moderate amounts of sporulation appeared on PDA and trianthema dextrose agar (TeDA) with woolly aerial mycelium. Significantly $(P<0.05)$ higher radial growth $(\mathrm{mm})$ of the isolate was recorded on PDA
$(80.67 \pm 1.76 \mathrm{~mm})$, followed by on CZA $(76.67 \pm 1.76$ $\mathrm{mm}$ ) on the 12th day. The diagnostic features of the isolate, such as phaeodictyoconidia and secondary sporulation, were observed. Conidiophores of the isolated fungus were stemphylioid in general appearance, simple, pale straw colored with 1-4 transeptate and very slightly swollen at apex. Conidiophores solitary or 2-4 were loosely fasciculate, erect, rarely distantly branched and simple with a single apical conidiogenous locus. G. trianthemae often proliferates by means of a secondary conidiophore that arises immediately bellow the apical cell of the existing conidiophores. Conidia were initially solitary, smooth, broadly ellipsoid to broadly sub ovate-ellipsoid, beakless, pigmented (pale yellow brown), becoming transversely and longitudinally septate (1-4 complete or partial transverse septa), apical cells swelling slightly and producing secondary conidia similar to initial ones (Fig. 1).

\subsection{Mycoherbicidal Efficiency of G. trianthemae}

An optimum $\left(5 \times 10^{4}\right.$ spore/mL $)$ spore suspension of $G$. trianthemae caused severe infection on host weed in vitro. The leaf spot disease was initiated as round to oval straw colored spots with maroon margins at initial stage of spore treated plants (test plants). The typical symptoms were examined on test plants at $3 \mathrm{~d}$ after inoculation. No symptoms were observed on control plants treated with sterile distilled water. After $24 \mathrm{~h}$ of incubation of test plants, small pinpoint maroon colored spots were examined on the surfaces of the leaves. These minute lesions on leaves were the result of the penetration of the germ tube or infectious structures on host tissue. An infection rate $(69.12 \% \pm 2.94 \%)$ was observed at 20 days after treatment (DAT), and the epidemic increased timely with increase of incubation period. The significant $(P$ $<0.05$ ) virulence of pathogen in terms of PDI was determined as $80.20 \pm 3.17,89.26 \pm 3.23$ and $94.56 \pm$ 2.82 on 30,40 and 50 DAT, respectively. The values are represented mean of five replicates and standard 

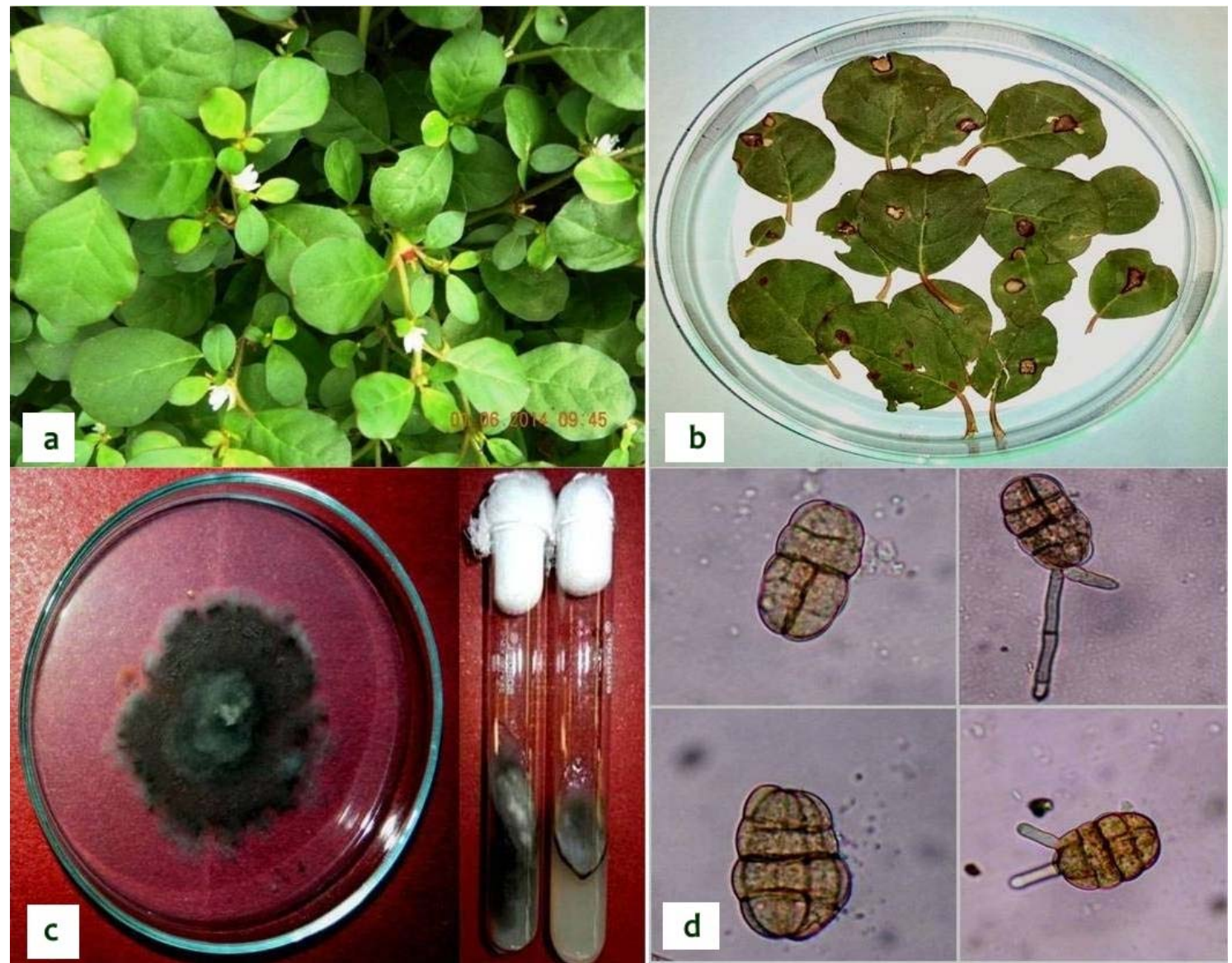

Fig. 1 The isolation of causal agent of leaf spot from infected leaf propagules.

(a): weed plant; (b): diseased leaves colony; (c): slant culture of the isolate G. trianthemae on PDA; (d): microscopic features of spores $(40 \times)$.

Table 2 Disease intensity on test plants inoculated with $G$. trianthemae spore inoculum at different days after treatment.

\begin{tabular}{lll}
\hline Concentration of inoculum & $\begin{array}{l}\text { Days after treatment } \\
(\mathrm{DAT})\end{array}$ & $\begin{array}{l}\text { PDI } \\
(\text { mean } \pm \mathrm{SE})\end{array}$ \\
\hline \multirow{3}{*}{$5 \times 10^{4}$ spores $/ \mathrm{mL}$ spore suspension +} & 20 & $69.12 \pm 2.94^{\mathrm{a}}$ \\
$0.02 \%$ Tween-20 & 30 & $80.20 \pm 3.17$ \\
& 40 & $89.26 \pm 3.23$ \\
\hline PDI & 50 & $94.56 \pm 2.82$ \\
\hline
\end{tabular}

PDI = percent disease index; SE $=$ standard error.

Values are represented mean of five replicates \pm standard error. ${ }^{a}$ Significant at the probability level of $5 \%(P<0.05)$.

error (Table 2). The environmental conditions, like 100\% moisture, temperature, nutrients and incubation period, enhanced the rate of infection on host, and in addition the susceptibility of the host plant and the virulence of the pathogen significantly increased the rate of infection. The increase of incubation time offers the favourable conditions, such as spore germination, the development of long germ tubes and appressoria (infection structures) and the germination of mycelial fragments.
Gibbago (pathogen)-Trianthema (host) pathosystem revealed the virulence of the pathogen as a promising mycoherbicide agent, which was highly potential to cause severe endemic on leaves, petioles, stem and other propagules of the target weed plant. The pathogenicity of $G$. trianthemae evaluated on different life stages, viz., growth stage-1 (3-5 foliage), growth stage-2 (6-10 foliage), growth stage-3 (11-14 foliage) and growth stage-4 (15-20 foliage) of target weed ( $T$. portulacastrum L.). Statistical analysis of the data on 
the inoculated plants revealed that percent infection was highly significant $(P<0.05)$ at various growth stages of the weed (Table 3 ). The early stage of the weed plant with 3-6 foliage favours the germination and penetration of the conidia of G. trianthemae - the infective propagules of the pathogen. The destructive damage of leaves and stems was examined on susceptible stage of the weed and caused 100\% mortality of the weed within short period.

\subsection{Future Prospect of G. trianthemae Simmons, a} Mycoherbicide Candidate

G. trianthemae cusses leaf spot disease on horse purslane weed at favourable conditions and controls the huge number of weed population in vitro and in vivo. Symptoms on leaves initiated as small pin point lesions at the early stage of infection. At maturity of the disease, the lesions occurred on leaves and stems and examined as round to oval straw colored spots with dark maroon borders. Spots expanded with the passage of time and became sunken, and caused the loss of tissue. As the disease progressed, affected leaves became chlorotic and dried up causing severe defoliation and withering of stems (Figs. 2 and 3). Stained sections of infective leaves showed the germination of conidia on host tissue and the penetration of pathogen into host by infection structures, i.e., appressoria. Plant tissue at the infected site was collapsed, and extensive ramification of the hyphae was examined in host leaf tissue under light microscopy. Field testing and laboratory observations (light microscopy) suggest that many factors need to be considered and optimized in the evaluation of Gibbago-Trianthema pathosystem. A series of epidemic surveys of plant pathogenic fungi associated with naturally infected horse purslane were conducted

Table 3 Disease intensity on test plants inoculated with $G$. trianthemae inoculum at different growth stages of horse purslane.

\begin{tabular}{lll}
\hline Concentration of inoculum & Growth stage of the weed & $\begin{array}{l}\text { PDI } \\
(\text { mean } \pm \text { SE) }\end{array}$ \\
\hline \multirow{2}{*}{$5 \times 10^{4}$ spores $/$ mL spore suspension +} & Stage 1 & $95.50 \pm 1.1^{\mathrm{a}}$ \\
$0.02 \%$ Tween-20 & Stage 2 & $87.04 \pm 2.0$ \\
& Stage 3 & $78.90 \pm 3.2$ \\
\hline
\end{tabular}

PDI = percent disease index; SE = standard error.

Values are represented mean of five replicates \pm standard error. ${ }^{a}$ Significant at the probability level of $5 \%(P<0.05)$.

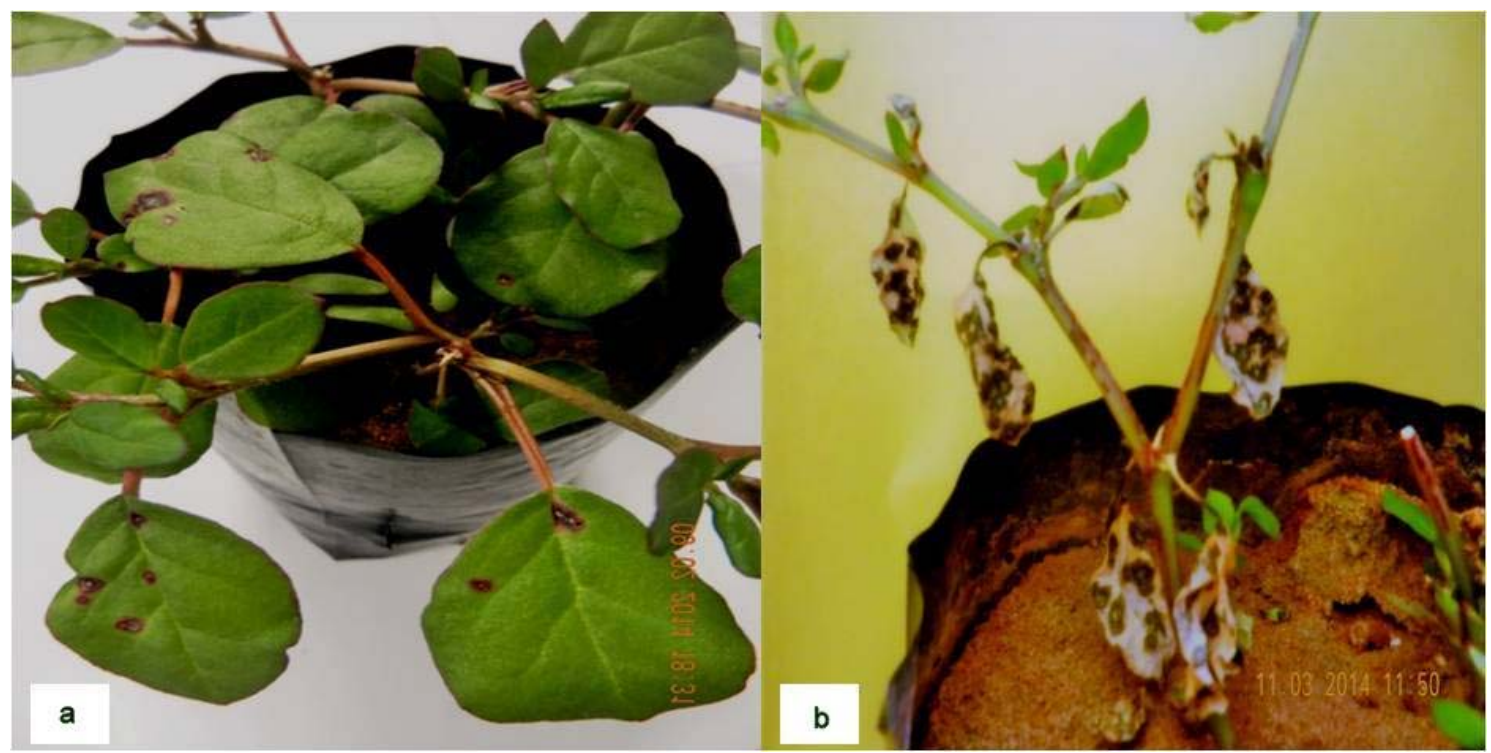

Fig. 2 Mycoherbicide activity of $G$. trianthemae on inoculated plants in vitro.

(a): initiation of leaf spot; (b): defoliation and mortality of weed horse purslane. 


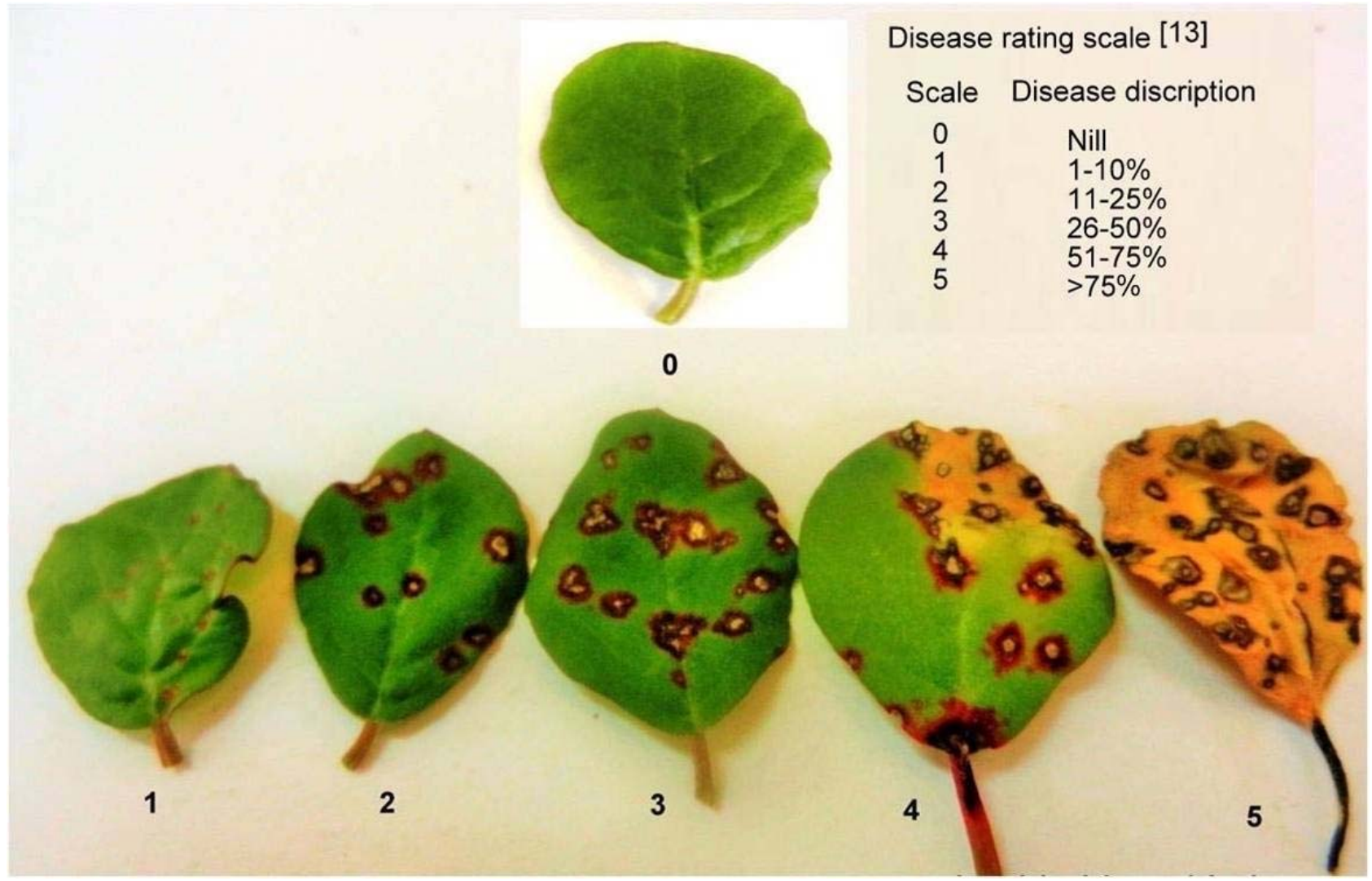

Fig. 3 Standard area diagram of horse purslane after inoculation and disease rating.

Disease rating scale is according to Ray and Hill [13].

in various countries, such as India, Texas (USA), Cuba, Venezuela and Pakistan. Fungal pathogens, namely, G. trianthemae [6, 8], Cercospora trianthemae [14], Drechslera (Exserohilum) indica (Bipolaris indica) [15, 16], Colletotrichum gloeosporioides [17], Fusarium oxysporum [17], Fusarium semitectum [18], Alternaria alternata [19, 20] and Phoma herbarum [21] have been reported on this weed around the world. Among them, the foliar pathogen $G$. trianthemae has shown biocontrol potential effectively to control horse purslane weed. The foliar pathogen $G$. trianthemae, as a new phaeodictyoconidial genus of hyphomycetes, was recorded on infected leaves of horse purslane in 1969 at Experimental Farm, University of Massachusetts by E.G. Simmons for first time in the world. Leaf spot disease of horse purslane weed due to the foliar pathogen $G$. trianthemae causing epiphytotics, was recorded by various workers in USA $[6,7]$, India $[8$,
22] and Pakistan [10], and the findings suggested the biocontrol potential of the pathogen. The fungal pathogen $G$. trianthemae can be highly aggressive towards horse purslane and has certain characteristics, such as highly virulence and host specificity to make a desirable candidate as biological control agent. These findings in this paper along with previous studies recommended the use of $G$. trianthemae as mycoherbicide at commercial level to control horse purslane weed.

\section{Conclusions}

Microbial-based pesticides (bioherbicides/ mycoherbicides) for the management of weeds are host specific, inexpensive and eco-friendly approaches. There has been a great number of naturally occurring fungal strains investigated for possible use as mycoherbicides, but only a small proportion has been developed to commercial products. These findings in 
this paper enlightened the mycoherbicide properties of G. trianthemae and concluded that it is an effective biocontrol agent to the target weed. The results also revealed that the horse purslane weed was controlled by the fungal pathogen $G$. trianthemae at field as well as green house conditions. The fungal pathogen $G$. trianthemae is highly virulent as well as host specific. The quantitative data on disease severity revealed the biocontrol potential of $G$. trianthemae as a successful mycoherbicide. The more extensive work is required to study pathogenicity, adaptability and dispersal and survival efficiency of the pathogen for the development of a commercial mycoherbicide. Type of strain and its virulence, variability in spore size and internal nutrients, spore hydration rate, spore adhesion to plant parts, the number of germ tubes per conidia, germ tube lengths, infection structures produced by germ tubes, the number of appressoria per conidia, penetration of plant parts, toxin productions, inoculum adjuvants, such as surfactants, interaction with other phylloplane microbes, etc., can affect the successes of a particular fungal isolate. The research in the direction of the development of mycoherbicide based on several field applications should be needed, and also the exploration of different virulent strains of $G$. trianthemae is obligatory to develop a successful mycoherbicide.

\section{Acknowledgments}

The authors were grateful to University Grants Commission (UGC), New Delhi, India for the financial assist under the scheme of UGC-SAP-CAS-I in the Department of Botany, Centre of Advanced Study, Andhra University, Visakhapatnam, India.

\section{References}

[1] Balyan, R. S., and Bhan, V. M. 1986. "Emergence, Growth and Reproduction of Horse Purslane (Trianthema portulacastrum L.) as Influenced by Environment Conditions." Weed Sci. 34 (4): 516-9.

[2] Aneja, K. R., Kumar, V., and Sharma, C. 2014. "Leaf Spot Disease of Trianthema portulacastrum, a New Record from World.” Journal of Innovative Biology 1 (2):
112-6.

[3] Charudattan, R. 1991. "The Mycoherbicides Approach with Plant Pathogens." In Microbial Control of Weeds, edited by TeBeest, D. O. New York: Chapman and Hall, 24-57.

[4] TeBeest, D. O., Yang, X. B., and Cisar, C. R. 1992. "The Status of Biological Control of Weeds with Fungal Pathogens." Annu. Rev. Phytopathol. 30: 637-57.

[5] Hasan, S. 1980. "Plant Pathogens and Biological Control of Weeds." Review of Plant Pathology 59: 349-56.

[6] Simmons, E. G. 1986. "Gibbago, a New Phaeodictyoconidial Genus of Hyphomycetes." Mycotaxon 27: 107-11.

[7] Mitchell, J. K. 1988. "Gibbago trianthemae, a Recently Described Hyphomycete with Bioherbicide Potential for the Control of Horse Purslane (Trianthema portulacastrum L.)." Plant Dis. 72 (4): 354-5.

[8] Aneja, K. R., and Kaushal, S. 1998. "Occurrence of Gibbago trianthemae on Horse Purslane in India.” J. Biol. Control. 12 (2): 157-9.

[9] Aneja, K. R., Khan, S. A., and Kaushal, S. 2000. "Management of Horse Purslane (Trianthema portulacastrum L.) with Gibbago trianthemae Simmons in India." In Proceedings of the $X$ International Symposium on Biological Control of Weeds, 27-33.

[10] Akhtar, K. P., Sarwar, N., Saleem, K., and Ali, S. 2013. "Gibbago trianthemae Causes Trianthema portulacastrum L. (Horse Purslane) Blight in Pakistan." Australasian Plant Dis. Notes 8 (1): 109-10.

[11] Wheeler, H. 1977. "Ultrastructure of Penetration by Helminthosporium maydis." Physiological Plant Pathology 11 (2): 171-8.

[12] Chaube, H. S., and Singh, U. S. 1991. Plant Disease Management: Principles and Practices. Boca Raton, Florida: CRC Press.

[13] Ray, P., and Hill, M. P. 2012. "Impact of Feeding by Neochetina weevils on Pathogenicity of Fungi Associated with Waterhyacinth in South Africa." J. Aquat. Plant Manag. 50: 79-84.

[14] Chiddarwar, P. P. 1962. "Contribution to Our Knowledge of the Cercospora of Bombay State-III." Mycopath. Mycol. Appl. 17 (1): 71-8.

[15] Taber, R. A., Mitchell, J. K., and Brown, S. M. 1988. "Potential for Biological Control of Weed Trianthema with Drechslera (Exserohilum) indica." Presented at the 5th International Congress of Plant Pathology, August 20-27, 1988, Kyoto, Japan.

[16] Rao, A. P., and Rao, A. S. 1987. "New Fungal Diseases of Some Weeds." Indian Bot. Repr. 6: 38.

[17] Darshika, P., and Daniel, M. 1992. "Changes in Chemical Content of Adhatoda and Trianthema due to Fungal Diseases.” Indian J. Pharmaceutical Sci. 54 (2): 73-5. 
[18] Darshika, S., and Daniel, M. 1998. "Two New Host Records of Fungi from Gujarat.” Indian Phytopath. 51 (2): 206.

[19] Bohra, B., Vyas, B. N., Godrej, N. B., and Mistry, K. B. 2005. "Evaluation of Alternaria alternate (Fr.) Keissler for Biological control of Trianthema portulacastrum L.." Indian Phytopathol. 58 (2): 184-8.

[20] Gupta, R., and Mukerji, K. G. 2001. "Environmental Effect on the Recurrence of Alternaria alternata on Trianthema portulacastrum." J. Environ. Biol. 22 (2): 83-6.
[21] Lakshmi, S. V., and Ray, P. 2013. "Evaluation of Indigenous Fungal Pathogens from Trianthema portulacastrum for Their Relative Virulence and Host Range Assessments to Select a Potential Mycoherbicidal Agent." Weed Sci. 61 (4): 580-5.

[22] Ratna Kumar, P. K., and Gaddeyya, G. 2014. "Host Specificity of Gibbago trianthemae Simmons, a Phaeodictyoconidial Hyphomycetes Fungus on Trianthema portulacastrum L. (Horse Purslane)." International Journal of Current Microbiology and Applied Sciences 3 (7): 461-70. 